\title{
ENCYSTED METACERCARIAE OF FAMILY HETEROPHYIDAE IN INFECTED FISH IN DAKAHLIA GOVERNORATE, AN ENDEMIC FOCUS IN EGYPT
}

\author{
By \\ MAI A. HEGAZI, AISHA T. HASSAN, THANAA M. AL-NASHAR, \\ OMAIMA I. ABO-ELKHEIR* and FATMA M. EL-LESSI \\ Departments of Parasitology and Community Medicine \& Public Health*, \\ Faculty of Medicine for Girls Al-Azhar University, Cairo \\ Abstract
}

The study re-evaluated the status of encysted metacercariae (EMC) of Family Heterophyidae in fresh and brackish water fish in an endemic focus in Egypt, as well as to study their morphological pattern. Seasonal variation of EMC was matched with their prevalence and intensity in infected fish. The study covered a period of one year from first of April 2011 to end of March 2012. The total percent of infection in the examined fish was $71.9 \%$ and $42.6 \%$ for brackish and fresh water respectively. The highest prevalence of the recovered EMC in both sources of water was for Heterophyes heterophyes $(57.9 \%)$, followed by Pygidiopsis genata (39.7\%), other Heterophyes spp. (21.09\%), Haplorchis pumilio (19.5\%), Phagicola spp (19.5\%) and Stictodora tridactyla (6.2\%). The highest mean intensity of the recovered EMC in both sources of water was for Pygidiopsis genata (10.27 \pm 2.83$)$, followed $H$. heterophyes (9.45 \pm 7.13$)$, Haplorchis pumilio (1.76 \pm 2.03$)$, Phagicola spp. (1.59 \pm 1.71$)$, other Heterophyes spp. (0.82 \pm 0.99$)$ and Stictodora tridactyla (0.48 \pm 0.92$)$. By using ANOVA test, there was significant difference in sizes of EMC of Pyigidiopsis genata $(\mathrm{P}=0.04)$ and Phagicola spp. EMC $(\mathrm{P}=0.03)$ in comparison to corresponding ones in all fish species. By using Student T-test, there was significant higher size of Haplorchis pumilio EMC in Tilapia species in comparison to the corresponding one in Mugil species. Monthly variation showed that summer was the season with the highest prevalence and highest mean intensity of EMC in both brackish and fresh water fish. Also, undifferentiated EMC most properly of genus Centrocestus was demonstrated.

Key words: EMC, Heterophyidae, Heterophyes, aequalis, dispar, Pygidiopsis, genata, Haplorchis, pumilio, Phagicola, longicollis, ascolonga, Stictodora, tridactyla

\section{Introduction}

Family Heterophyidae (Odhner, 1914) includes a set of over 50 genera having similar morphological features (Waikagul and Thaenkham, 2014). The main zoonotic genera are Metagonimus, Heterophyes (H), Centrocestus, Pygidiopsis, Stellantchasmus, Haplorchis and Procerovum (Chai and Lee, 1990), Stictodora, Heterophyopsis, Diochitrema, Phagicola, Appophalus, Cryptocotyle, Plagiorchis, Brachylaima, Cotylurus and Carneophallus (Berger and Marr, 2006). In Egypt, the recorded genera and species of family Heterophyidae were Heterophyes heterophyes, $H$. aequalis, Pygidiopsis genata, Haplorchis pumilio, Ha. taichui, Ha. yo-kogawi, Stictidora tridactyla, Phagicoal longicollis, Ph. ascolonga and $P h$. italica (El-Sheikha and El-Sahazly, 2008b), H. dispar (Mürrell and Fried, 2007), $H$. nocens, $H$. katsuradi (Shalaby et al, 2006), Haplorchis pleurolophocerca (Berger and Marr, 2006), Stictodora sawakinensis (Witenberg, 1928), Centrocestus cuspidatus (Bowman et al, 2008), C. formosanus (ElTantawy and El-Naggar, 2002), C. armatus (Ibrahim et al, 2009), C. unequiorchalis (Saad, 1994). The first intermediate hosts of family Heterophyidae are different species of snails while second one harboring EMC are different species of fish (Witenberg, 1929). Definitive hosts are fish eating ani- 
mals or birds and human consuming raw or incompletely cooked fish (Dzikowski et al, 2003). Heterophyiasis is commonly found in Far East, Palestine, Mediterranean Countries, Hawaii, Ukraine, Canada and Al-aska (Seo et al, 1984; Chai and Lee, 1990; Dixon, 1997) and a zoonotic problem in Egypt (Shams El-Din, 2011) with H. heterophyes high infection rates (Chai and Lee, 2002). In Egypt, coastal regions inhabitants showed highest incidence of heterophyiasis (33.8\%) than other helminthes in El-Meaddeya (Abou-Basha, 2000) and 13.3\% in Northern Egypt suffered from heterophyiasis (Lobna et al, 2010). They added that infection rate was $22 \%$ in brackish water and $42 \%$ in fresh water fish Besides, between 79.2\% and $100.0 \%$ in all fish in Manzala Lake (Mugil spp. and Tilapia spp.) were infected with $H$. heterophyes EMC (El-Sheikha and ElShazly, 2008a). Also, in fresh water canal in Ismailia Governorate T. zilli $(95.37 \%)$ were infected with heterophyid EMC (Ibrahim and Soliman, 2010). The rate of infection with heterophyid metacercariae was $37.9 \%$ of Mullet, Liza auratus fish in Lake Manzala (Ghobashy et al, 2010). In heterophyiasis, noticeable symptoms of diarrhea, abdominal pain, loss of appetite and nausea occur in the final host as result of inflammation due to worm attachment to the mucosa of the intestine and releasing of eggs. Susceptibility of children may be more (Parija et al, 2003).

Eggs released in the intestine can be trapped into the blood stream and embolize in various regions of the body, particularly with tissue reactions in the heart valves and myocardium causing cardiac failure as well in the central nervous system (Schmidt and Roberts, 2009). Eosinophilia is often present in heterophyiasis infections (Parija et al, 2003).

The aim of the present work was to review the current status of encysted metacercariae (EMC) of family Heterophyidae in brackish and fresh water fish as the intermediate host in an endemic focus (Dakahlia Governorate) in Egypt

\section{Materials and Methods}

Mugil (M) and Tilapia (T) fish species (spp), the common intermediate host of fam Mugil $(M)$ and Tilapia (T) fish species (spp), the common intermediate host of fam ily Heterophyidae, were collected form the Nile River at Al-Mansoura City as fresh water source and Al-Manzala Lake as brackish water source. The later one is heterophyiasis an endemic focus with high transmission rate. Fish samples were obtained from local fishermen twice monthly over one year from the beginning of April 2011 till the end of March 2012. The total number of fish was 887; 385 Mugil spp. (M. cephalus, M. capito, and M. auratus) and 502 Tilapia spp. (T. nilotica and $T$. zilli). Fish samples were transferred in ice-box to the laboratory and screened for the presence of any EMC by the naked eye or added by a hand lens (Mahdy et al, 1995). About 30 snips of each fish were taken from different parts mainly from the head, dorsum and tail regions as well as visceral organs, fins and gills. The EMC were identified microscopically (Elsheikha and Elshazly, 2008a). Different types of metacercariae were separated into 6 groups according to their morphology (diameters, shape, thickness of cyst wall, and pigments content). Separation of EMC from infected fish by artificial digestion method was done (Yokogawa and Sano, 1968). The digested material was filtered through a sieve and washed several times with $0.85 \%$ physiological saline. Different types of EMC were collected from the sediment and segregated using a binocular dissecting stereomicroscope. Each group of $50 \mathrm{EMC}$ was given orally to 5 puppies (healthy, aging two months and weighing about $3 \mathrm{~kg}$ ) in $10 \mathrm{ml}$ of phosphate buffered saline solution ( $\mathrm{pH}$ 7.6) by using stomach tube and mouth gage. One week later, infection in puppies was confirmed by stool examination. Infected puppies were anaesthetized and sacrificed after 3 weeks post-infection (PI). The intestine 
was taken in one piece and opened. The mucosa was scraped gently and the contents were collected and transferred to clean dish containing warm saline to prevent the contraction of the worms. The contents were transferred to a conical flask. The supernatant fluid was removed and the deposit was washed several times in warm saline to remove any debris. The parasites were collected and preserved in $70 \%$ alcohol. The collected worms were stained with acetic acid alum carmine then identified microscopically on morphological basis (Witenberg, 1929). The prevalence and mean intensity of different EMC in fish tissues from different sources of water were done (Margolis et al, 1982).

Statistical analysis: Data were computed and analyzed by using SPSS for Windows version 15.0. Student T-test and ANOVAtest (F-test) were used for comparing data. $\mathrm{P}$ value $\leq 0.05$ was considered significant.

\section{Results}

Table 1: Percent infection of total examined fish with heterophyid EMC over one year in different water of Tilapia and Mugil fish

\begin{tabular}{|l|c|c|c|c|c|c|}
\hline \multirow{2}{*}{ Water Sources } & \multicolumn{3}{|c|}{ Prevalence (\%) } & \multicolumn{3}{|c|}{ Intensity (cyst/gm.) } \\
\cline { 2 - 7 } EMC spp. & $\begin{array}{c}\text { Manzala } \\
\mathrm{L} . \\
(\mathrm{N}=636) \\
\left(\mathrm{N}^{\prime}=457\right)\end{array}$ & $\begin{array}{c}\text { Mansoura } \\
\mathrm{N} . \\
(\mathrm{N}=251) \\
(\mathrm{N}=107)\end{array}$ & $\begin{array}{c}\text { Total } \\
(\mathrm{N}=887) \\
(\mathrm{N}=564)\end{array}$ & $\begin{array}{c}\text { Manzala } \\
\text { L. }\end{array}$ & $\begin{array}{c}\text { Mansoura } \\
\mathrm{N} .\end{array}$ & Total \\
\hline H. heterophyes & $\begin{array}{c}71.6 \% \\
(\mathrm{n}=327)\end{array}$ & $\begin{array}{c}0.0 \% \\
(\mathrm{n}=0)\end{array}$ & $\begin{array}{c}57.9 \% \\
(\mathrm{n}=327)\end{array}$ & $\begin{array}{c}1 \\
3.23 \pm 4.56\end{array}$ & $0 \pm 0$ & $9.45 \pm 7.13$ \\
\hline Other Heterophyes & $\begin{array}{c}26.03 \% \\
(\mathrm{n}=119)\end{array}$ & $\begin{array}{c}0.0 \% \\
(\mathrm{n}=0)\end{array}$ & $\begin{array}{c}21.09 \% \\
(\mathrm{n}=119)\end{array}$ & $1.15 \pm 1.005$ & $0 \pm 0$ & $0.82 \pm 0.99$ \\
spp. & $\begin{array}{c}38.9 \% \\
(\mathrm{n}=178)\end{array}$ & $\begin{array}{c}42.9 \% \\
(\mathrm{n}=46)\end{array}$ & $\begin{array}{c}39.7 \% \\
(\mathrm{n}=224)\end{array}$ & $2.95 \pm 2.07$ & $4.16 \pm 4.103$ & $10.27 \pm 2.83$ \\
\hline Pygidiopsis genata & $\begin{array}{c}15.09 \% \\
(\mathrm{n}=69)\end{array}$ & $\begin{array}{c}38.3 \% \\
(\mathrm{n}=41)\end{array}$ & $\begin{array}{c}19.5 \% \\
(\mathrm{n}=110)\end{array}$ & $1.41 \pm 1.60$ & $2.62 \pm 2.69$ & $1.76 \pm 2.03$ \\
\hline Haplorchis pumilio & $\begin{array}{c}19.7 \% \\
(\mathrm{n}=90)\end{array}$ & $\begin{array}{c}18.6 \% \\
(\mathrm{n}=20)\end{array}$ & $\begin{array}{c}19.5 \% \\
(\mathrm{n}=110)\end{array}$ & $1.55 \pm 1.56$ & $1.70 \pm 2.07$ & $1.59 \pm 1.71$ \\
\hline Stictodora tridacty- & $\begin{array}{c}7.7 \% \\
(\mathrm{n}=35)\end{array}$ & $\begin{array}{c}0.0 \% \\
(\mathrm{n}=0)\end{array}$ & $\begin{array}{c}6.2 \% \\
(\mathrm{n}=35)\end{array}$ & $0.68 \pm 1.03$ & $0 \pm 0$ & $0.48 \pm 0.92$ \\
\hline la
\end{tabular}

Table 2: Grouping and morphological characters of recovered EMC

\begin{tabular}{|c|c|c|c|c|}
\hline \multirow{2}{*}{ Water source } & Fish spp. & No. of examined & No. of infected & \% of infection \\
\hline \multirow{2}{*}{ Manzala Lake } & Mugil & 385 & 294 & 76.4 \\
\cline { 2 - 5 } & Tilapia & 251 & 163 & 64.9 \\
\hline Total & Mugil \& Tilapia & 636 & 457 & 71.9 \\
\hline Mansoura Nile & Tilapia & 251 & 107 & 42.6 \\
\hline Both water sources & All spp. & 887 & 564 & 63.6 \\
\hline
\end{tabular}


Table 4: Total prevalence and total mean intensity of different spp. of heterophyid EMC infecting all fish spp. from fresh and brackish water sources along one year

\begin{tabular}{|c|c|c|c|c|c|c|}
\hline \multirow{3}{*}{$\begin{array}{l}\text { Source of } \\
\text { mater/fish sp } \\
\text { Morphomet- } \\
\text { ric character }\end{array}$} & \multicolumn{6}{|c|}{ Groups of EMC } \\
\hline & $\begin{array}{l}\text { Heterophyes } \\
\text { spp. heavy pig- } \\
\text { ments }\end{array}$ & $\begin{array}{l}\text { Heterophyes } \\
\text { spp. few pig- } \\
\text { ments }\end{array}$ & $\begin{array}{l}\text { Pyigidiopsis } \\
\text { genata }\end{array}$ & $\begin{array}{c}\text { Haplorchis } \\
\text { pumilio }\end{array}$ & Phagicola spp. & $\begin{array}{l}\text { Stictodora } \\
\text { tridactyla }\end{array}$ \\
\hline & $\begin{array}{l}\text { Manzala L. } \\
\text { (T. \& M.) }\end{array}$ & $\begin{array}{l}\text { Manzala L. } \\
\text { (T. \& M.) }\end{array}$ & $\begin{array}{l}\text { Manzala L. } \\
\text { (T. \& M.) } \\
\text { Mansoura N. } \\
\text { (T.) }\end{array}$ & $\begin{array}{l}\text { Manzala L. (T. } \\
\text { \& M.) } \\
\text { Mansoura N. } \\
\text { (T.) }\end{array}$ & $\begin{array}{l}\text { Manzala L. (T. } \\
\text { \& M.) } \\
\text { Mansoura N. } \\
\text { (T.) }\end{array}$ & $\begin{array}{l}\text { Manzala } \\
\text { L. (T. \& } \\
\text { M.) }\end{array}$ \\
\hline Shape & Spherical & Spherical & Spherical & Spherical & Spherical & Oval \\
\hline Color & Yellow & Yellow & Yellow & Transparent & Yellow & Yellow \\
\hline Cyst wall $(\mu)$ & thick (5-10) & thick (5-10) & Thin (1-4) & Thin (2-5) & Thick (25-30) & thin $(2-7)$ \\
\hline Pigments & 1or 2 masses & few & none & none & none & none \\
\hline $\begin{array}{l}\text { Common } \\
\text { sites in fish }\end{array}$ & $\begin{array}{c}\text { muscles mainly } \\
\text { near tail }\end{array}$ & $\begin{array}{l}\text { muscles ma- } \\
\text { inly near tail }\end{array}$ & $\begin{array}{l}\text { muscles ma- } \\
\text { inly near tail }\end{array}$ & $\begin{array}{c}\text { muscles mainly } \\
\text { near tail }\end{array}$ & viscera and gills & $\begin{array}{l}\text { viscera } \\
\text { and gills }\end{array}$ \\
\hline Presentation & Single & Single & in groups & Single & Single or groups & Single \\
\hline
\end{tabular}

N.B.: T. =Tilapia, M. = Mugil, L. =Lake, N. = Nile Branch

\section{Discussion}

In the present study, Mugil spp. was obtained from Manzala Lake, while Tilapia spp. was obtained from both, Manzala Lake and Mansoura Nile. In Manzala Lake the total percent of infection was $71.9 \% ; 76.4 \%$ for Mugil spp. and $64.9 \%$ in Tilapia spp. In Mansoura Nile it was $42.6 \%$ only for Tilapia spp. The total percent of infection in both sources of water was $63.6 \%$. The percent of infection with all heterophyid EMC in the present study was higher than that of Ghobashy et al. (2010) who reported that the rate of heterophyid infection in $M$. auratus and T. nilotica was $37.9 \%$ in Manzala Lake. Also, Lobna (2010) reported that the overall prevalence of heterophyid EMC infection in Tilapia spp. was $32 \%$ in the same location. This may be due to more pollution of water at the timing of the present study. The present study recorded higher percent of infection in brackish water fish $(71.9 \%)$ than in fresh water fish $(42.6 \%)$ with EMC. Rifaat et al. (1980) reported that the prevalence of heterophyid infection of the fish spp. from Manzala Lake was higher than that in fish spp. from the Nile in Dakahlia Governorate. Also, Mugil spp. attained higher percent of infection $(76.4 \%)$ than that of Tilapia spp. from Manzala Lake (64.9\%) and Mansoura Nile (42.6\%). In accordance to the present result is El-Sheikha and El-Shazly (2008a) recorded the total percent prevalence of het- erophyid EMC in fish spp. in Manzala lake as the following; M. cephalus $(29.7 \%)$, followed by $M$. auratus $(29.1 \%)$, M. capito (23.2\%), T. nilotica (17.6\%) and the lowest prevalence was in T. zilli (16.4\%). Also, Ghobashy et al. (2010) recorded that the total percent prevalence of heterophyid infection in Manzala Lake as 37.9\% in M. auratus and $7.9 \%$ in T. niloticus. Lobna et al. (2010) reported nearly the same overall prevalence of infection $(42 \%)$ for fresh water fish but much lower percent for for brackish water fish and (22\%). Even in comparing between Tilapia spp. from the two different sources of water, the total percent prevalence of heterophyid EMC in Manzala Lake was higher $(64.9 \%)$ than in Mansoura Nile (42.6\%). The higher percent of infection in Manzala Lake for the same genera of fish could be explained by the fact that Manzala Lake is exposed to higher pollution with parasitic pathogens due to sewage and irrigation drainage from the major surrounding governorates in Nile Delta (Mageed, 2007; Barakat et al, 2012). No sanitary facilities for many fishermen and their families living around Lake Manzala with frequent water contact make all excreta pass into the lake with additive pollution (Azab et al, 2013). Pollution of Manzala Lake water leads to endimicity of many parasitic diseases including schistosomiasis mansoni. (Taman et al, 2014) 
In the present study, EMC of Heterophyes spp. with heavy pigments, or with few pigments and Stictodora tridactyla EMC were found only in brackish water source; Manzala Lake. This may be due to presence of Pirinella conica as the first intermediate host of these EMC in the Egyptian Lakes (El-Gindy and Hanna, 1963), while, Pygidiopsis genata, Haplorchis pumilio and Phagicola spp. EMC were found in brackish and fresh water sources; Manzala Lake, and Mansoura Nile. The first intermediate host recorded for Pygidiopsis genata and Haplorchis pumilio is Melania tuberculata found in estuarine waters and the bottom of fresh water (Farahnak et al, 2005). The snail host of Phagicola longicollis is still unknown (Macpherson et al, 2013).

In the present study, five genera of heterophyid EMC were detected in Mugil and Tilapia spp. They were Heterophyes, Pyigidiopsis, Haplorchis, Phagicola and Stictodo$r a$. EMC detected in fish muscle tissue especially tail region were Heterophyes spp. with heavy or with few pigments, Pygidiopsis genata, and Haplorchis pumilio. The same genera of heterophyid EMC were detected in Egypt (Makhlouf et al, 1987; Mansour et al, 1987; Youssef et al, 1987; Gillespie and Pearson, 2001; Mürrell and Fried, 2007; El-Sheikha and El-Shazly, 2008a; Ibrahim and Soliman, 2010; Taraschewski and Nicolaidou, 2009). The tail was the maximally infected region with heterophyid EMC in Mugil and Tilapia spp (Shalaby et al, 2007). Trunk or head of the fish are considered, by other authors, the regions with most affection with heterophyid EMC in T. nilotica fish followed by the tail (Mousa et al, 2000).

EMC detected in fish gills and viscera in the present study were St. tridactyla and Phagicola spp. recorded. The same EMC was reported in gills and viscera (El-Sheikha and El-Shazly, 2008b; Hassan et al, 2012; Martorelli et al, 2012).

On searching for viable heterophyid EMC on the internet, no videos were available.
The videos of the present study were uploaded on line on YouTube for scientific benefits.

After sacrificing the experimentally infected puppies with grouped EMC from different fish spp., the following adult worms of family Heterophyidae were recovered: $H$. heterophyes from EMC of Heterophyes spp. with heavy pigments, $H$. aequalis \& $H$. dispar from EMC of Heterophyes spp. with few pigments, Pygidiopsis genata from EMC of Pygidiopsis genata, Haplorchis pumilio from EMC of Haplorchis pumilio, Phagicola longicollis \& Phagicola ascolonga from EMC of Phagicola spp. and Stictodora tridactyla from EMC of Stictodora tridactyla.

In Egypt, other species of the same genera found in the present study were detected. Among these were the H. nocens, H. katsuradi by Shalaby et al. (2006), H. katsuradi by Mürrell and Fried (2007) and Haplorchis pleurolophocerca spp by Berger and Marr (2006). Witenberg (1929) recorded Stictodora sawakinensis spp. In Egypt, another genus of family Heterophyidae which was not detected in the present study is Prohemostomum vivax (El-Sheikha and El-Shazly (2008a). the authors considered it as a member of family Heterophyidae, while Müller (2002) and Macpherson et al. (2013) considered it as a specie of family Cathycotylidae which was recovered from dogs, cats and rarely in man.

In the present study, the size of different spp. of obtained EMC from different spp. of fish in the different sources of water did not show significant difference in size of $H$. heterophyes, other Heterophyes spp. and S. tridactyla EMC in comparison to corresponding ones in all species of fish. By using ANOVA test, there was significant difference in size of EMC of $P$. genata, and Phagicola spp in comparison to corresponding ones in all fish. By using Student T test, there was significant higher size of Haplorchis pumilio EMC in Tilapia in comparison to the corresponding one in Mugil fish spp, 
without significant differences in size or morphology of all EMC in all collected fish (El-Sheikha and El-Shazly (2008b).

On comparing the prevalence and mean intensity of different obtained EMC, $H$. heterophyes in Manzala Lake showed the highest prevalence $(71.6 \%)$ and mean intensity (13.23 $\pm 4.56 \mathrm{cyst} / \mathrm{gm}$.), followed by $P$. genata $(38.9 \%, 2.95 \pm 2.07)$, Heterophyes spp. (26.03\%, 1.15 1.005$)$, Phagicola spp. $(19.7 \%, 1.55 \pm 1.56), H$. pumilio $(15.09 \%$, $1.41 \pm 1.60)$ respectively. The lowest prevalence and the lowest mean intensity were $7.7 \%$ and $0.68 \pm 1.03 \mathrm{cyst} / \mathrm{gm}$ for Stictodora tridactyla respectively. This agreed with ElSheikha and El-Shazly (2008a) as H. heterophyes was the most prevalent spp. of heterophyid EMC followed by the $P$. genata, Phagicola spp., H. aequalis, Haplorchis spp. and lowest prevalence was in Stictodora spp. El-Sheikha and El-Shazly (2008a) recorded that the highest prevalence of $H$. heterophyes EMC in all fish in Manzala Lake $79.2 \%$ and $100.0 \%$ in Mugil and Tilapia spp, respectively

In Mansoura Nile, highest prevalence and mean intensity (cyst/gm) was showed by $P y$. genata $(42.9 \%, 4.16 \pm 4.103)$, followed by $H$. pumilio $(38.3 \%, 2.62 \pm 2.69)$ and Phagicola spp. (18.6\%, 1.70 \pm 2.07$)$. This agreed with Makhlouf et al. (1987) who recorded highest prevalence and intensity in Pygidiopsis genata EMC in all Mansoura Nile Tilapia fish spp; (26.6 \%, 6 cyst/gm) in T. nilotica and $(16.9 \%, 6 \mathrm{cyst} / \mathrm{gm})$ in $T$. zilli. In the present study, prevalence of heterophyid EMC in Mansoura Nile were lower than that recorded by Ibrahim and Soliman (2010) who recorded that the highest prevalence for the Phagicola spp. (93.64\%), followed by $H$. yokogawi (47.4\%) and lowest was in Pygidiopsis genata $(21.4 \%)$, in $T$. zilli from Ismalia fresh water canal.

The seasonal pattern in heterophyid EMC infection could be of considerable importance in planning for parasite control (Sithithaworn et al, 1997). In the present study, higher prevalence and mean intensity of EMC in both sources of water were in summer, lowest in winter and in-betweens in spring and autumn, with direct proportional to water temperature. El-Sheikha and ElShazly (2008a) recorded the highest heterophyid EMC prevalence in summer $(38.2 \%)$, followed by the spring (26.6\%), autumn $(19.3 \%)$, and lowest in winter $(8.7 \%)$ in Manzala Lake fish spp. Lobna et al. (2010) reported that the prevalence of heterophyid EMC was highest in summer $(46.4 \%)$, followed by spring $(37.5 \%)$, autumn $(27.3 \%)$ and lowest prevalence in winter $(15.4 \%)$ in Tilapia fish spp. in Northern Egypt.

As regard intensity of EMC in infected fish, El-Sheikha and El-Shazly (2008a) recorded significant differences in the intensity of heterophyid EMC in different brackish water fish spp where the highest seasonal intensity was in summer, followed by spring, then autumn and lowest intensity was in winter in Manzala Lake; fish hosts were massively parasitized in summer with low level in winter. Abou-Zakham et al. (1990) recorded that the highest intensity of the infection with Stictodora tridactyla EMC in Mugil sp. and Tilapia sp. collected from Manzala Lake was in summer. Ibrahim and Soliman (2010) detected three spp. of EMC in $T$. zilli from Ismalia fresh water canal. They were; H. yokogawi, Phagicola ascolonga and Pygidiopsis genata. Summer was the season with highest intensity of the three spp, followed by autumn and lowest was in winter. But, they recorded significant differences in the intensity of Phagicola ascolonga being higher in summer, but $H$. yokogawi and Pygidiopsis genata intensity showed no significant response to seasonal variation. Mansour et al. (1987) reported the highest intensity in spring and the lowest intensity in winter in the study of Tilapia spp. infected with $H$. heterophyes in three brackish water Lakes; Manzala, Borollos and Idku.

The present study showed a harmony between total percent prevalence and total mean intensity of different spp of EMC; the higher prevalence was almost accompanied 
by higher intensity and vice versa. This symmetrical fluctuation of the mean intensity and prevalence agreed with El-Sheikha and El-Shazly (2008a) who recorded that the variation in the intensity of heterophyid EMC in different fish spp. runs parallel to the fluctuation in their prevalence, and that these results may be due to the fact that both the intensity and the prevalence of heterophyid EMC in fish are affected by the same factors. Makhlouf et al. (1987) recorded that the prevalence and intensity of heterophyid EMC infection rise and fall in a seasonal pattern explained by the temperaturedependent release of cercariae. An increase in the prevalence of parasitic infections was related to the reproductive and breeding season of both snails and fish (Bello et al, 2000; Simkova et al, 2005). The decreased level of EMC during the cold season may be explained by death of the cercariae and EMC (El-Sheikha and El-Shazly, 2008a).

In the present study, some undifferentiated EMC were different fish spp. were found in few numbers and weren't regularly presented in all months; and their differentiation experimentally was difficult. Among the undifferentiated rarely detected EMC, there were two remarkable cysts obtained from the intestine of the examined fish in Mansoura Nile T. nilotica and T. zilli. The first one showed an $\mathrm{X}$-shaped excretory bladder which was very similar to that of $C$. formosanus. The second one had a V-shaped excretory bladder which was very similar to that of $C$. cuspidatus. Reda et al. (2010) recorded the presence of EMC of genus Centrocestus in gills of T. nilotica fish in Egypt. C. formosanus EMC affect the skin, muscles, gill cavity, gills, eyes, liver, spleen, kidney, bladder and intestine of fish. It is considered as a cause of death in T. nilotica cultured fish within 30 days post infection (Cortes et al, 2010). This may explain rarity of finding such EMC in examined fish in the present study. El-Tantawy and El-Naggar (2002) reported EMC of C. formosanus inhabitant $H$. bloyeti fish. C. formosanus adults were found in definitive hosts' intestine and rarely implicated as risky (Cortes et al, 2010). Martin (1959) Crewe and Ashford (2003) and Bowman et al. (2008) recorded the presence of $C$. cuspidatus EMC in Egypt. Mohamed et al. (2005) reported $C$. cuspidatus EMC in crayfish and shrimps collected from Sharkia, Ismalia and Port Said Governorates.

\section{Conclusion}

The outcome data showed high incidence of Heterophyidae in Lake Manzala fish and in the Mansoura Nile River. This threatens the health of citizens in surrounding areas and makes the fish retrieved from there a source for the spread of infection among consumers.

\section{Recommendations}

Directing sewage and agricultural drainage water away from Lake Manzala and Nile is powerfully recommended to prevent the inflow of eggs found in feces with recurring infection of the snail and subsequently fish by cercariae. This will prevent the spread of heterophyiasis, as well as a lot of parasitic diseases

\section{Acknowledgment}

To Dr. Atef M. El-Shazly soul, Professor of Parasitology, Faculty of Medicine, Mansoura University whose memory remains by his valuable publications.

\section{References}

Abou-Basha, LM, Abdel-Fattah, M, Orecchia, P, Cave, D, Zaki, A, 2000: Epidemiological study of heterophyiasis among humans in an area of Egypt. East. Mediterr. Hlth. J. 6, 5/6: 932-8.

Abou-Zakham, A, El-Shazley, A, El-Ganayni, F, Romia, SA, Abou-Shady, AF, et al, 1990: Seasonal variation and incidence of Stictodora tridactyla in fish from lake Manzala. J. Egypt. Soc. Parasitol. 20, 1:117-21.

Azab, MM, Darwish, AA, Mahmoud, HA, Sdeek, FA, 2013: Residue levels of organochlorine pesticides in some ecosystem components of Manzala Lake. Environ. Monit. Assess. 185, 12:10257-68.

Barakat, AO, Mostafa, A, Wade, TL, Swe-et, ST, El Sayed, NB, 2012: Assessment of persis- 
tent organochlorine pollutants in sediments from Lake Manzala, Egypt. Mar. Pollut. Bull. 64, 8: 1713-20.

Bello, AR, Fortes, E, Bello-Klein, A, Bello, AA, Llesuy, SF, et al, 2000: Lipid peroxidation induced by Clinostomum detruncatum in muscle of the freshwater fish Rhamdia quelen. Dis. Aquat. Org. 42:233-6.

Berger, SA, Marr, JS, 2006): Human Parasitic Diseases. Jones \& Bartlett Learning.

Bowman, DD, Hendrix, CM, David, S, Lindsay, S, Barr, C, 2008: Feline Clinical Parasitology. John Wiley \& Sons.

Chai, JY, Lee, SH, 1990: Intestinal trematodes of humans in Korea: Metagonimus Heterophyids and Echinostomes. Korean J. Parasitol. 28:10322.

Chai, JY, Lee, SH, 2002: Food-borne intestinal trematode infections in the Republic of Korea. Parasitol. Int. 51:129-32.

Crewe, S, Ashford, R, 2003: Parasites of Homo sapiens: An Annotated Checklist of Protozoa, Helminths \& Arthropods for which we are Home, $2^{\text {nd }}$ ed., CRC Press, USA and Canada.

Dixon, BR, Flohr, RB, 1997): Fish- and shellfish-borne trematode infections in Canada. Southeast Asian J. Trop. Med. Pub. Hlth. 28, 1:58-64.

Dzikowski, R, Diamant, A, Paperna, I, 2003: Trematode metacercariae of fish as sentinels for a changing immunological environment. Dis. Aquat. Org. 55:145-50.

El-Gindy, MS, Hanna, EY, 1963: Larval trematodes from snails Pirenella conica and Melania tuberculata with special reference to heterophyiasis. Bull End. Dis. 5:33-58.

El-Sheikha H.M, El-Shazly, AM, 2008a: Hostdependent variations in the seasonal prevalence and intensity of heterophyid encysted metacercariae (Digenea: Heterophyi- dae) in brackish water fish in Egypt. Vet. Parasitol. 153: 65-72.

El-Sheikha H.M, El-Shazly, AM, 2008b: Preliminary observations on infection of brackish and fresh water fish by heterophyid encysted metacercariae in Egypt. Parasitol.1Res.103:9717.

El-Tantawy, SA, El-Naggar, AMA, 2002: Observations on the encystment and encapsulation of metacercaria of Centrocestus formosanus (Digenea: Heterophyidae) with a report on other gill inhabitants of the lesser perch, Haplochromis bloyeti in Egypt. Proceed. Int. Conf. Biol. Sci. 2:2-8.
Farahnak, A, Setodeh, S, Mobedi, I, 2005: A faunistic survey of cercariae isolated from Melanoides tuberculata and role in diseases transmission. Arch. Razi. Ins. 59:113-9.

Ghobashy, MA, Soliman, MFM, Hassan, EA, 2010: Responses of the Mullet, Liza auratus and the Cichlid, Oreochromis niloticus from Lake Manzala (Egypt) to heterophyid infection. Int. J. Zool. Res. 6:13-23.

Gillespie, S, Pearson, RD, 2001: Principles and Practice of Clinical Parasitology. John Wiley \& Sons.

Hassan, EA, Soliman, MFM, Ghobashy, A FA, 2012: Some factors affecting metacercarial infections in Tilapia zilli from Lake Timsah, Ismailia, Egypt. Egypt. Acad. J. Biol. Sci. 4, $1: 21-8$.

Ibrahim, MM, Soliman, MFM, 2010: Prevalence and site preferences of heterophyid metacercariae in Tilapia zilli from Ismailia fresh water canal, Egypt. Parasite 17:233-9.

Ibrahim, M, Abel-Ghany, A, Emeash, H, et al, 2009: Epidemiological studies on the role of fish in transmitting some zoonotic diseases to man. Vet. Med. J. Giza, 57:169-85.

Lobna, SMA, Metawea, YF, EI-Sheikha, HM, 2010: Prevalence of heterophyiasis in Tilapia fish and humans in Northern Egypt, Parasitol. Res. 107, 4:1029-34.

Mageed, AA, 2007: Distribution and long-term historical changes of zooplankton assemblages in Lake Manzala (south Mediterranean Sea, Egypt). Egypt. J. Aquat. Res. 33, 1:183-91.

Mahdy, OA, Essa, MA, Easa, MES, 1995: Parasitological and pathological studies in Tilapia sp. from Manzala Egypt. J. Comp. Pathol. Clin. Pathol. 8:131-45.

Makhlouf, LM, Abou-Zakham, A, El-Khouly, EI, Abou-Shady, AF, Abdel-Magied, S A, et al, 1987: Heterophyids of fresh water fish from Mansoura, Egypt. J. Egypt. Soc. Parasitol. 17, 2:573-9.

Mansour, NS, Youssef, M, Awadalla, HN, Hammouda, NA, Boulos, LM, 1987: Heterophyid metacercariae in the fish Tilapia sp. (cichlidae) from Edku, Maryout and Manzala Lake in Egypt. J. Egypt. Soc. Parasitol. 17: 481-93.

Margolis, L, Esch, GW, Holmes, JC, Kur- is, AM, Schad, GA, 1982: The use of ecolo- gical terms in parasitology J. Parasitol. 68: 131-3.

Martin, WE, 1959: Egyptian heterophyid trematodes. Trans. Am. Micros. Soc. 78, 2:17281. 
Martorelli, SR, Lino, A, Marcotegui, P, Montes, MM, Alda, $P$, et al, 2012: Morphological and molecular identification of the fishborne metacercaria of Ascocotyle (Phagicola) longa Ransom, 1920 in Mugil liza from Argentina. Vet. Parasitol. 190:599-600.

Mousa, WM, Mahdy, OA, Kandil, OM, 2000: Electrophoretic analysis to confirm the identification of some kinds of encysted metacercariae from Oreochromis niloticus Assiut, Vet. Med. J. 43, 85:199-209.

Mürrell, KD, Fried, B, 2007: Food-borne parasitic zoonoses: Fish and plant-borne parasites. Wld. Class Parasit. 1175.

Odhner, T, 1914: Die Verwandscha Ftsnezied Unger der Trematoden gattung Parago-nimus. Brn. Zool. Bidray, 3:231-46.

Parija SC, Thomas, JM, Koirala, J, Shekhar, A, 2003: Trematode infection. E. Med.

Reda, RM, El-Nobi, GA, Hassanin, ME, ElHady MA, El-Bouhy, ZM, 2010: Study On Some EMC "DigeneticTrematodes" Affecting Gills Of Oreochromus niloticus, 10th Sci. Vet. Med. Zag. Conf. Egypt.

Rifaat, MA, Salem, SA, El-Kholy, SL, Hegazi, MM, Yousef, ME, 1980: Studies on the incidence of Heterophyes heterophyes in Dakahlia Governorate J. Egypt. Soc. Parasitol. 10, 2:36973.

Saad, AI, 1994: The life cycle of Centrocestus unequiorchalis n. sp. (Heterophyidae: Centrocestiinae). J. Islamic Acad. Sci. 7, 3:193-8.

Seo, BS, Lee, SH, Chai, JY, Sung-Jong, H, 1984: Studies on intestinal trematodes in Korea: XII. Two cases of human infection by Stellantchasmus falcatus. Korean J. Parasitol. 22.1: 43-50.

Shalaby, SI, Anter, O, Hassan, N, El-Mahdy, M, Mohamed, I, et al, 2006: Clinical manifestations of experimentally induced fish-borne trematode infection in experiment-tal animals. J. Curr. Sci. 9:443-8.

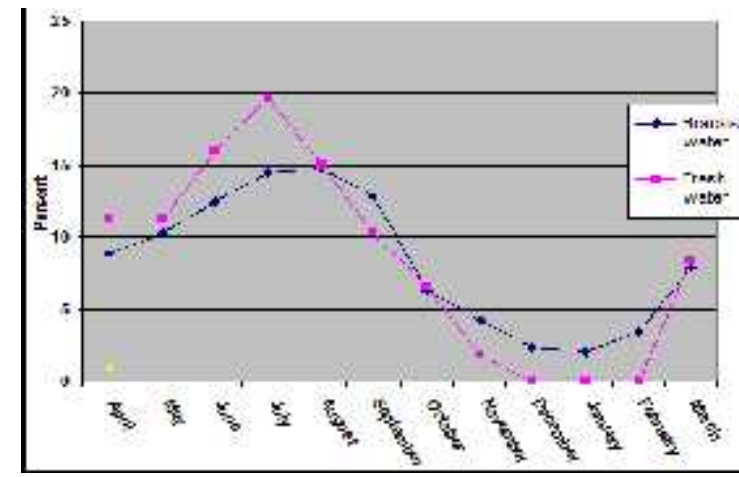

Chart 1: Monthly prevalence of EMC of family Heterophyidae in brackish and fresh water sources
Shalaby, SI, Shalaby, SIA, El-Mahdy, M, Anter, O, Hassan, N, et al, 2007: Parasitological and pathological analysis of trematode cyst infestations in Tilapia nilotica, T. zilli and Mugil cephalus. J. Parasitic Dis. 31, 1:38-43.

Shams-El-Din, SA, 2011: Histopathological, histochemical and immune-histochemical studies of experimental heterophyiasis in dogs and the Protecting Role of Praziquantel. Res. Article, PUJ, 4, 2:185-92.

Simkova, A, Jarkovsky, J, Koubkova, B, Barus, V, Prokes, M, 2005: Associations between fish reproductive cycle and the dynamics of metazoan parasite infection. Parasitol. Res. 95:6-72.

Taman, A, El-Tantawy, N, Besheer, T, Taman, S, Helal, R, 2014: Schistosoma mansoni infection in a fishermen community, the Lake Manzala region-Egypt, the Asian Pacific J. Trop. Dis. 4, 6:463-8.

Taraschewski, H, Nicolaidou, A, 2009: Heterophyes species in Greece: record of H. heterophyes, $H$. aequalis and $H$. dispar from the first intermediate host, Pirenella conica. J. Helminthol. 61, 1:2832.

Waikagul, J, Thaekham, U, 2014: Approaches to Research on the Systematics of Fish-Borne Trematodes, Academic Press.

Witenberg, G, 1929: Studies on the trematode family Heterophyidae. Ann. Trop. Med. Parasitol. 23, 2:131-9.

Yokogawi, M, Sano, M, 1968: Studies on the intestinal flukes IV. On the development of the worm in the experimental infected animals with metacercariae of Metagonimus yokogawi. Japan Parasitol. 17:540-8.

Youssef, MM, Mansour, NS, Hammouda, NA, Awadalla, HN, Khalifa, R, et al, 1987: Studies on some developmental stages in the life cycle of pygidiopsis genata (trematoda :Heterophyid-ae) from Egypt. J. Egypt. Soc. Parasitol. 17, 2: 463-73.

Zahran, MA, 2008: The Vegetation of Egypt. Springer, ISBN 1-4020-8755-1

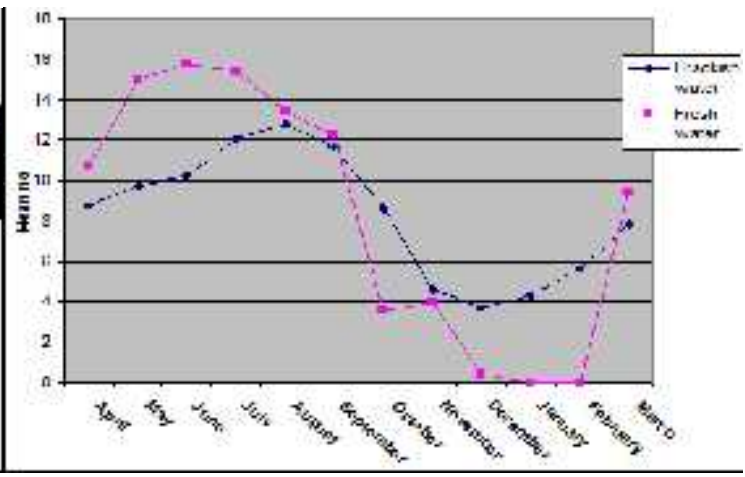

Chart 2: Monthly mean intensity of EMC of family Heterophyidae in brackish and fresh water sources 

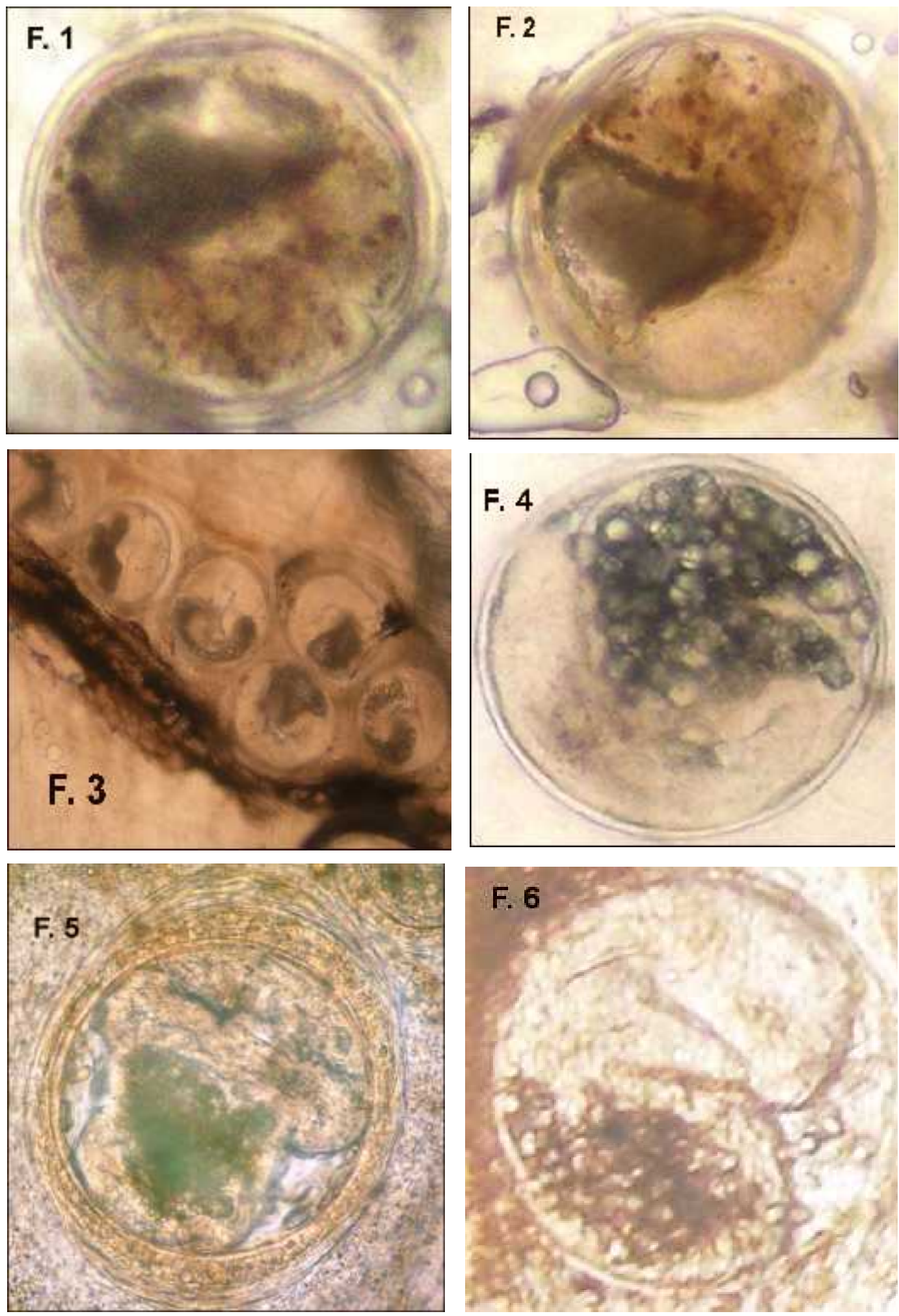

1- EMC of Heterohyes sp. with heavy pigments in H. heterohyes

2- EMC of Heterohyes sp. with few pigments in H. aequalis and H. dispar,

3- EMC of Pyigidiopsis genata in Pyigidiopsis genata

4- EMC of Haplorchis pumilio in Haplorchis pumilio

5- EMC of Phagicola spp. in Phagicola longicollis and Phagicola. ascolonga

6- EMC of Stictodora tridactyla in Stictodora tridactyla 

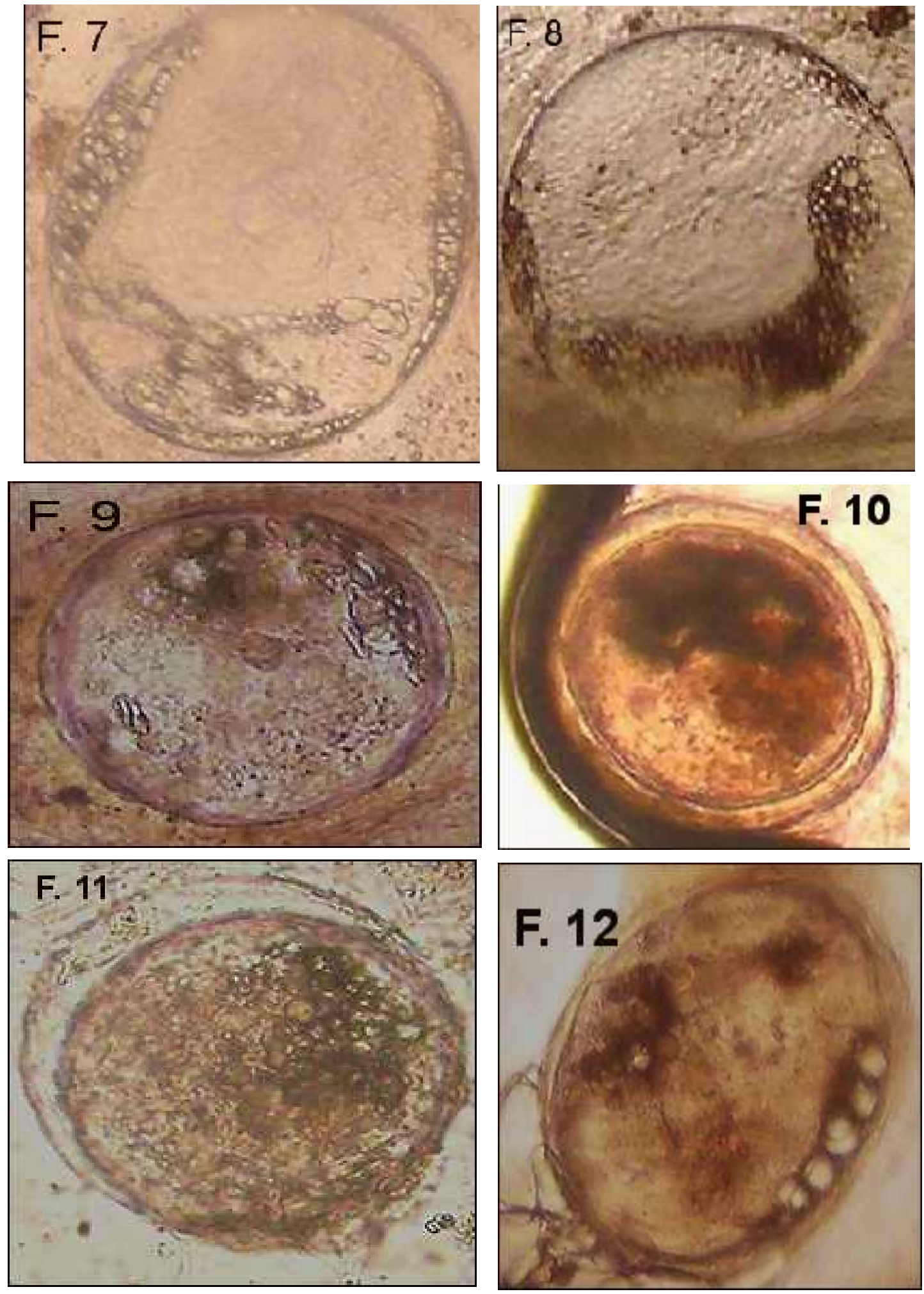

Undifferentiated EMC separated from different fish spp. $\times 200$, (Digital Camera)

Fig 7: EMC in Mansoura Nile, Tilapia species (nilotica \& zilli) in intestine Fig 8: EMC in Mansoura Nile, Tilapia species (nilotica \& zilli) in intestine Fig 9: EMC in Manzala Lake, Tilapia species (nilotica \& zilli) in intestine Fig 10: EMC in Mansoura Nile, Tilapia species (nilotica \& zilli) in intestine Fig 11: EMC in Mansoura Nile Tilapia species (nilotica \& zilli) in intestine Fig 12: EMC in Manzala Lake, Tilapia species (nilotica \& zilli) in muscle 


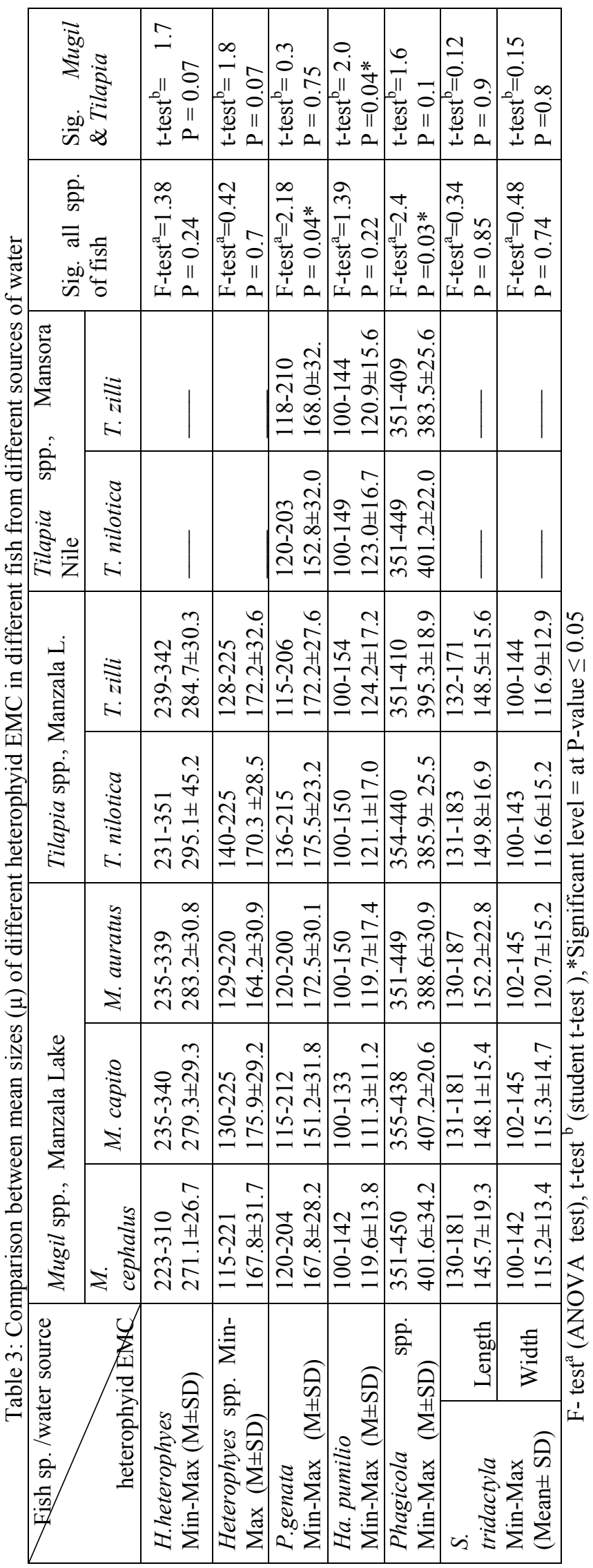

